\title{
Variability of agroecosystems and landscape service provision on the urban-rural fringe of Wuhan, Central China
}

\author{
Ting Zhou ${ }^{1} \cdot$ Jan E. Vermaat ${ }^{2} \cdot$ Xinli Ke ${ }^{3}$
}

Published online: 20 August 2019

(C) The Author(s) 2019

\begin{abstract}
Urbanization drives changes in peri-urban farmland use which probably affects the spatial pattern of landscape service provision. This study charts patterns in these services and analyses the impacts of biophysical and social-economic factors such as land use allocation and proximity. A spatially explicit survey was conducted among 767 farmer households on the urban-rural fringe of rapidly urbanizing Wuhan (China). The hypothesis of a largely linear change with distance from the urban centre was tested separately for 7 quantified landscape services with RDA and regression analysis. Significant linear patterns were found for 4 landscape services: food, vegetables and fruits, trees, and storm water runoff reduction. Air pollution mitigation and recreation were found to be associated with nearby water rather than green infrastructure, which is likely due to the abundance of water around Wuhan. In addition, storm water runoff reduction correlated with green infrastructure (grasslands and forests). Bundling of landscape services was found to vary along the urban-rural fringe, with recreation and air pollution mitigation bundled at the urban end, while ponds and recreation bundled in the rural outer zone. In short, several provisioning and regulating services varied linearly with distance, whereas others did not, due to the strong geographical forcing by water.
\end{abstract}

Keywords Peri-urban farmland use · Urban-rural gradient · Landscape service bundles · Drivers · Landscape planning · Urbanization

\section{Introduction}

Agroecosystems are multifunctional and provide society with a range of valuable landscape services (Dale and Polasky 2007). These can be material services such as food, fiber and bioenergy, to regulating services including water filtration, carbon sequestration, and cultural ones such as hunting,

Ting Zhou

t.zhou@vu.nl

Jan E. Vermaat

jan.vermaat@nmbu.no

Xinli Ke

kexl@igsnrr.ac.cn

1 Department of Spatial Economics, Vrije Universiteit Amsterdam, De Boelelaan 1105, 1081, HV Amsterdam, the Netherlands

2 Faculty of Environmental Sciences and Natural Resource Management, Norwegian University of Life Sciences, pobox 5003, 1432 Ås, Norway

3 Department of Public Administration, Huazhong Agricultural University, No.1, Shizishan Street, Hongshan District, Wuhan 430070, People's Republic of China cultural heritage and recreation. Provisioning services generally contribute direct value to the livelihoods of famers, whereas benefits of regulating and cultural services from these open and green spaces often accrue more widely and can be beneficial to the inhabitants of adjacent cities (Bryant and Johnston 1992; Bontje 2001). Particularly around large, expanding cities, the urban-rural fringe is a zone of rapid change, where the importance of several services changes and competing forms of land use can cause complex conflicts (Seto et al. 2012; UN 2014). Peri-urban agriculture tends to be more specialized, for example in the form of horticulture, and the urban-rural fringe may provide multiple services through e.g. hobby farming, horse-keeping and social farming (Zasada et al. 2012).

Changes in the structure and pattern of farmland should also modify the spatial pattern of landscape services provided by agroecosystems (Hou et al. 2015; Simon 2008; TorresLima and Rodríguez-Sánchez 2008). For example, services such as food and water supply, aesthetic and spiritual services can be dominant at the rural end of the gradient where agricultural and less intensive land use types prevail (Kroll et al. 2012; Łowicki and Walz 2015; Radford and James 2013). Indeed, a recent comparative study of four European cities 
showed a higher supply of recreation towards the rural end of the gradient, whereas other services, specifically local climate regulation, did not follow a typical urban-rural gradient (Larondelle and Haase 2013). This is in contrast to the findings of Raudsepp-Hearne et al. (2010), who studied service bundles in peri-urban Quebec, Canada, and found that one bundle of provisioning services excluded a different bundle of regulating and cultural services, hence they observed no correlation of rural food provision and recreation. Similarly, Queiroz et al. (2015) found that biodiversity appreciation and cross-country skiing were concentrated in the urban areas of Stockholm, in contrast with the forest products and moose hunting that associated with peripheral forested areas. Nearest to the city, peri-urban farmland may well be subject to higher or increasing demands for some particular services than further away from the city (Casado-Arzuaga et al. 2013; Hou et al. 2015). For example, travel distance puts an upper limit to recreational use (Rossi et al. 2015) and this may create a distinct banding. Moreover, places with water ponds are appreciated for providing recreational opportunities (FrühMüller et al. 2016; Plieninger et al. 2013).

In short, there is little evidence to expect uniformity in the distribution of landscape services along the urban-rural gradient, and their underlying drivers can be manifold. To analyse this spatial variability, we quantified 7 different landscape services (Table 1) provided by agroecosystems along the urbanrural fringe of a rapidly urbanizing city, Wuhan, in central China. Using spatially explicit survey data and locally available statistics, we analyse the spatial variability of these landscape services as well as covariance with possibly explanatory underlying factors. Based on the literature cited above, we postulate that the patterns are largely linear with distance (see Suarez-Rubio et al. 2012, and Rossi et al. 2015, for more complex alternatives) so that larger, cash-crop oriented farms are more frequent towards the rural end of the gradient, whereas the urban end is characterized by more heterogeneity and smaller farms. In parallel, air pollution mitigation and Storm water runoff reduction, as well as recreation increase towards the rural end, the latter most likely also in areas with a high incidence of ponds (Früh-Müller et al. 2016).

\section{Materials and methods}

\section{Study area}

The study was performed in Wuhan, a rapidly expanding city surrounded by productive farmland in central China. There is a population of 10 million people in Wuhan with more than $80 \%$ living in the urban area, and this proportion is expected to increase further in the near future (Hubei Bureau of Statistics 2015). This increase is accompanied with urban sprawl, which likely puts pressures on farmland. Wuhan's area covers
$8569 \mathrm{~km}^{2}$, of which half is farmland (Hubei Bureau of Statistics 2015).

Located in the east of the Jianghan Plain (one of the thirteen main food baskets in China), the low hills are favourable for cultivation with slopes ranging from 0 to 9.6 degree and elevations between 7 and $61 \mathrm{~m}$. Moreover, the lowland location at the confluence of the Yangtze and Han rivers provides highly fertile soils. In addition, the climate is highly suitable for agriculture with a mean annual temperature of $17{ }^{\circ} \mathrm{C}$ (China meteorological administration 2016), and sufficient rainfall and sunshine for year-round production. The main agricultural products are rice, wheat, cotton, corn, sweet potato, peanut, and rapeseed oil.

Wuhan is known as "The city of hundreds of lakes" for the high number of lakes within the city. The high availability of surface water area not only motivates the presence of a fishery industry, but also provides recreational opportunities. The urban periphery is surrounded by a broad rural gradient with considerable variation in land use, providing landscape services of variable quality and quantity. According to the local land use planning, around 5\% of the cropland in Wuhan should be developed into highly productive fields during the 13th five-year (2016-2020), and this is expected to grow in the longer term (Government of Hubei province 2016). Wuhan is also planning to develop a modern urban agricultural system based on multiple uses of farmland (Wuhan Land Resources and Planning Bureau 2011).

\section{Farm household survey}

A questionnaire was designed focusing upon local farmer households with their land within the urban-rural fringe of Wuhan. The urban-rural fringe we studied is an approximately $10 \mathrm{~km}$ wide belt connecting the contiguous and predominantly urban area of Wuhan city with its mostly agricultural surroundings. Several transects fanning out in different directions from the city centre were laid out to cover the whole urban-rural fringe (Fig. 1). From a pre-test among 90 local farmers in six villages in early November of 2015, land-use practices and socio-economic characteristics of farmer households were found to be similar within the same village, therefore two farmer households were selected randomly for interviews in one village. If the selected household was not available, another household next door was interviewed. The questionnaire was adjusted according to the pre-test and carried out in late November and December of 2015.

Farmer residences were given a short introduction of our study purpose. We subsequently interviewed one of the family members, generally the head of the household or someone else most familiar with the farmland conditions. We asked about farmland conditions, farming practices as well as socialeconomic characteristics of the household. For each household, we recorded the answers, and acquired the geographic 
Table 1 Indicators used for the selected landscape services and potentially underlying factors including data sources. All the indicators are quantified per household and per year for 2015. The survey is explained in section 2.3

\begin{tabular}{|c|c|c|}
\hline & Indicators [Abbreviations are the labels used in Fig. 2] & Data source \\
\hline \multirow[t]{4}{*}{ Provisioning services } & $\begin{array}{l}\text { Food (proportion of area with food crops in the total area of } \\
\text { farmland in the household) [Food] }\end{array}$ & Survey \\
\hline & $\begin{array}{l}\text { Vegetables \& fruits (proportion of the area with vegetables \& } \\
\text { fruits in the total area of farmland in the household) [Veg_ } \\
\text { Fruit] }\end{array}$ & Survey \\
\hline & Ornamental trees (proportion of the land under trees) [Trees] & Survey \\
\hline & $\begin{array}{l}\text { Ponds with fish and lotus (proportion of the household area } \\
\text { with ponds) [Ponds] }\end{array}$ & Survey \\
\hline \multirow[t]{3}{*}{ Regulating services } & $\begin{array}{l}\text { Air pollution mitigation }(1=\text { no difference; } 2=\text { small } \\
\text { difference; } 3=\text { medium difference; } 4=\text { large difference; } \\
5=\text { extremely large difference between where they live } \\
\text { and the nearest urban centre) [Air] }\end{array}$ & Survey \\
\hline & Storm water runoff reduction $(100 \mathrm{~cm})[$ Storm $]$ & Soil: China Soil Database; \\
\hline & & $\begin{array}{l}\text { Precipitation: The ground meteorological } \\
\text { observatory in Hubei Province }\end{array}$ \\
\hline Cultural services & $\begin{array}{l}\text { Recreation (number of paid visits per household per year, } \\
\quad \times 1000 \text { for scale) [Recreation] }\end{array}$ & Survey \\
\hline \multirow[t]{8}{*}{ Underlying factors } & Share of forest in $1 \mathrm{~km}$ buffer zone (fraction) [Forest\%] & \multirow{4}{*}{$\begin{array}{l}\text { Data Centre of Resources and Environment, } \\
\text { Chinese Academy of Science (Liu et al. 2010) }\end{array}$} \\
\hline & $\begin{array}{l}\text { Share of grassland in } 1 \mathrm{~km} \text { buffer zone (fraction) } \\
\text { [Grassland\%] }\end{array}$ & \\
\hline & Share of water in $1 \mathrm{~km}$ buffer zone (fraction) [Water\%] & \\
\hline & $\begin{array}{l}\text { Share of built-up area in } 1 \mathrm{~km} \text { buffer zone (fraction) } \\
\text { [Built-up\%] }\end{array}$ & \\
\hline & Production potential $(\times 1000$ for scale) $[$ Prod] & IIASA/FAO et al. (2012); Liu et al. (2014) \\
\hline & $\begin{array}{l}\text { Distance from farmer residence to the nearest urban districts } \\
(\mathrm{km}) \text { [Dis_urban] }\end{array}$ & \multirow{3}{*}{$\begin{array}{l}\text { Survey, Traffic Atlas of Wuhan Traffic Atlas of } \\
\text { Wuhan (http://tourist.beixinluqiao. } \\
\text { net/download/6194137.html) }\end{array}$} \\
\hline & $\begin{array}{l}\text { Distance from farmer residence to the nearest minor road } \\
(\mathrm{km}) \text { [Dis_road] }\end{array}$ & \\
\hline & Share of family members with off-farm jobs [Off-farm] & \\
\hline
\end{tabular}

coordinates with a GIS mobile app ViewRanger. We visited a total of 987 farmer households, but some of them were not interviewed if we were told their lands were recently converted to non-agricultural use. In the end, we surveyed 797 farm households and obtained 767 responses (96\% response rate).

\section{Identification and quantification of landscape services}

A suite of landscape services was identified following the framework established by Common International Classification of Ecosystem Goods and Services (CICES) (Haines-Young and Potschin 2010) with three main concerns: (1) the importance to local farmers and adjacent urban residents' demands; (2) a potentially high priority to decision makers; and (3) the availability of a quantitative proxy that is available in recent spatial databases or could be quantified from survey data. The chosen landscape services, their indicators and respective sources are summarized in Table 1.

Provisioning services such as food and materials are inherent in agriculture (Dale and Polasky 2007). The main crops planted in the study area were obtained from the household interviews. Accordingly, we classified five types of provisioning services: food, vegetables and fruits, trees (ornamental trees) and ponds. Their relative importance is estimated from the share in the total farm area in the farming household in the past recent 12 months (Dale and Polasky 2007). As part of the farmland belonging to a household may be abandoned, the sum of these proportional indicators can be smaller than 1 .

Peri-urban farmlands are documented to contribute to air quality improvement through the filtering by trees and other crops (Pearson et al. 2010). Air pollution mitigation is estimated from the farmers appreciation using a Likert-scale (Koschke et al. 2012; Langemeyer et al. 2014). Local farmers were asked to rate how they perceived the difference in air quality between where they live and the most adjacent urban centre. The value ranges from 1 (no difference) to 5 (much better with cleaner air where they live than in the nearest urban centre). In addition, farmland can contribute to the retention of storm water runoff through various agricultural practices. As Wuhan city reportedly is flooded with increasing frequency in recent decades (http://www.hbqx.gov.cn/index.action), the role of farmland in mitigating this by retaining storm water runoff can be considered an important regulating service. We 

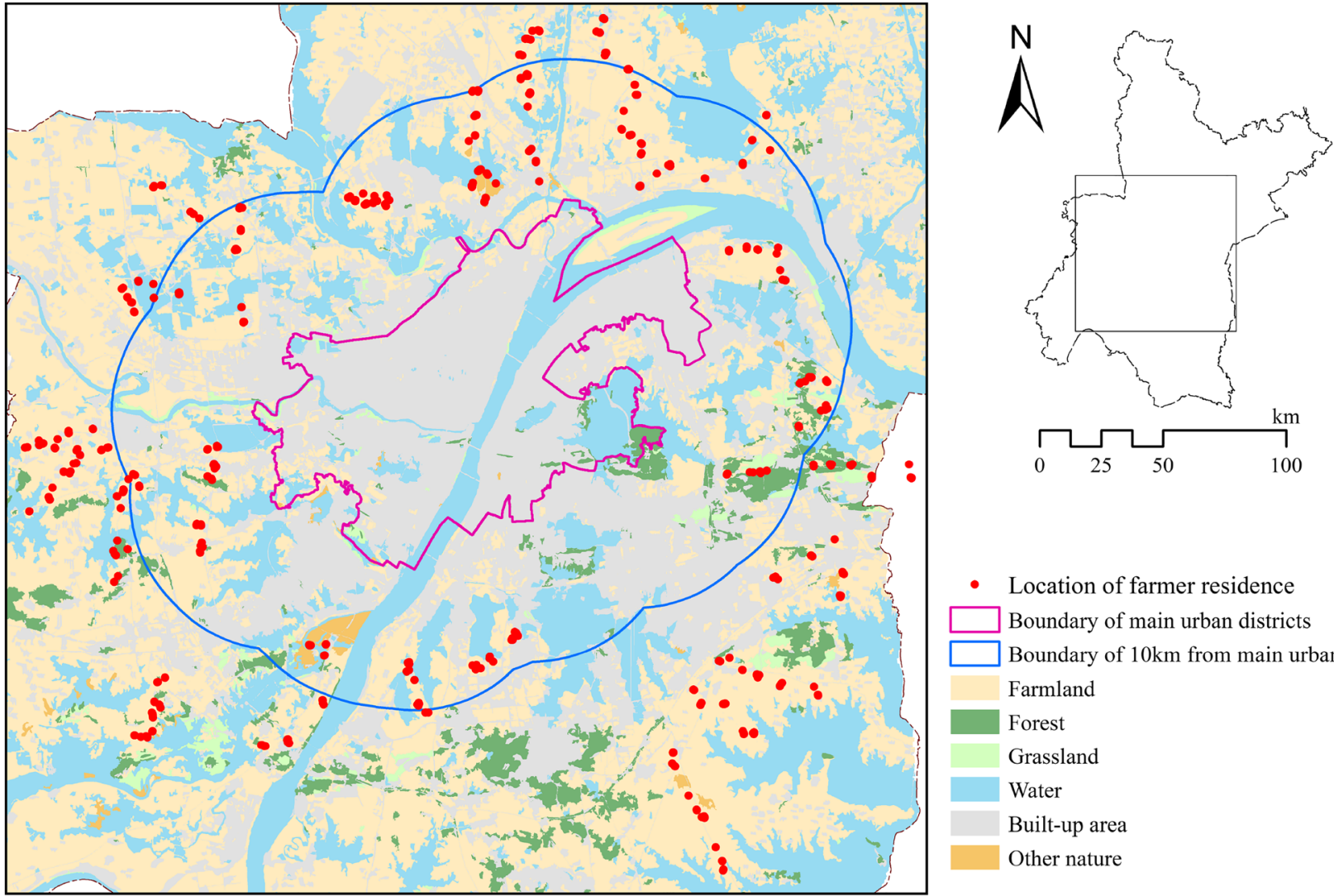

- Location of farmer residence

Boundary of main urban districts

Boundary of $10 \mathrm{~km}$ from main urban districts Farmland

Forest

Grassland

Water

Built-up area

Other nature

Fig. 1 Location of the surveyed farmer residences. Note that many are too closely overlapping at the current scale to be shown individually

used storm water runoff reduction, an indicator to measure the maximum potential rainfall retention potential (S) for a site (USDA-NRCS 1986; Whitford et al. 2001). The approach is based on USDA-Soil Conservation Service (SCS 1972) and further developed by Pandit and Gopalakrishnan (1996) using:

$\mathrm{Q}=\frac{(P-0.2 S)^{2}}{P+0.8 S}$

$\mathrm{S}=\frac{2540}{C N}-25.4$

where $\mathrm{Q}$ is the runoff depth $(\mathrm{cm})$ and $\mathrm{P}$ is the precipitation $(\mathrm{cm}) . \mathrm{S}$ is the maximum potential retention once runoff begins and related to the soil and cover condition of farmland according to $\mathrm{CN}$ (curve numbers). $\mathrm{CN}$ is tabulated by SCS with a value ranging from 0 to 100 for a particular combination of land cover type, soil hydrological group (a categorization of soil type based on infiltration rates, which is strongly related to soil texture) and antecedent soil moisture conditions (a categorization of how dry or wet the soil is before a precipitation event). Tabulated $\mathrm{CN}$ values were taken from USDA-NRCS (1986) (Whitford et al. 2001). Recreation was selected as the most recognizable and appreciated cultural service (Gilhespy 2013). This indicator has been acquired from the farm household survey.

\section{Data analysis}

The pre-test survey indicated that most farmers own more than one parcel of farmland, and these parcels are scattered, which complicates the mapping of the location for each farmland parcel. Therefore, we analysed locations of farmer residences instead of the location of farmland plots (Fig. 1). The 767 locations of farmer residences were recorded during the interviews by a mobile app ViewRanger and then registered to land use map by a standard desktop geographical information system (ArcGIS 10.4). ArcGIS was used to prepare datasets of underlying factors as well as a match the provided landscape services with the corresponding farmer household.

To make all the datasets consistent in format and spatial resolution, they were converted to raster datasets. The surrounding land use configuration for an individual respondent farmer household was calculated for a $1 \mathrm{~km}$ buffer from the household location with each of four land use types: forest, grassland, water, and built-up area.

We used the potential agricultural yield as an index of farmland quality, which is determined by climate, soil, water resource, and irrigation. It is calculated with the Global AgroEcological Zones (GAEZ) model following IIASA/FAO et al. (2012) and Liu et al. (2014). The average climatic conditions during 1990-2010 with spatial resolution of $1 \mathrm{~km}$ is taken to 
represent the potential agricultural yield in study year, presuming that the potential agricultural yield remains stable in recent decades (Liu et al. 2014).

In addition, the Near function in ArcGIS was applied to acquire the following accessibility data: (1) the distances from the locations of farmer household to the main urban area; and (2) the distances from the locations of farmer household to the nearest minor road. Furthermore, impermeability was derived by calculating NDISI (Normalized Difference Impervious Surface Index) with remote sensing data (Cui et al. 2015). Overall descriptive statistics of the indicators of landscape services and underlying factors are presented in Table 2.

To test the covariance between landscape services and impact from potentially underlying factors, we carried out a redundancy analysis (RDA) (Martín-López et al. 2012). We did two separate RDAs for the inner $(\leq 10 \mathrm{~km})$ and outer fringe $(>10 \mathrm{~km})$. This simple breakdown of the gradient follows Zasada et al. (2012) and allows an analysis of overall patterns, ignoring fine-scale spatial variation.

\section{Results}

Multiple linear regressions of the provision of landscape services and underlying factors were applied to test our hypotheses (Table 3). As postulated, food, representing larger, cash-crop oriented farms was more frequent towards the rural end of the gradient. Storm water runoff reduction increased towards the rural end as well. In contrast, ornamental trees were more abundant closer to the urban area. Different from our hypothesis, Vegetables and fruits were found to be more clustered closer to the urban centre. Other services did not follow this urban-rural pattern.

We analyzed covariance among services and underlying factors for two spatial zones (within and beyond $10 \mathrm{~km}$ from the main urban area). RDA results revealed two main components explaining $34 \%$ of the total variance in both zones (Fig. 2). The loading plots of RDA analysis representing the first two axes suggested that the overall pattern is largely the same in these two zones, while some bundling occurred, though differently in inner and outer zone. For example, the recreation and air pollution mitigation bundled at the urban end, while ponds and recreation bundled in the rural outer zone.

Provisioning services did not show a strong covariance, whereas recreation strongly related to nearby water and storm water runoff reduction covaried with permeable grasslands and forests. Air pollution mitigation clearly covaried with a higher proportion of nearby water, but only in the zone within $10 \mathrm{~km}$ from the urban centre. This could be related to the strong negative correspondence between the share of water and built-up area around the farmland.
Table 2 Descriptive statistics of landscape service indicators and potentially explanatory underlying factors

\begin{tabular}{|c|c|c|c|c|c|}
\hline Indicators & Obs. & Mean & $\begin{array}{l}\text { Std. } \\
\text { Dev. }\end{array}$ & Min & Max \\
\hline \multicolumn{6}{|l|}{ Landscape services } \\
\hline Food & 732 & 0.29 & 0.40 & 0 & 1 \\
\hline Vegetables \& fruits & 732 & 0.25 & 0.38 & 0 & 1 \\
\hline Trees & 732 & 0.11 & 0.28 & 0 & 1 \\
\hline Ponds & 732 & 0.69 & 0.23 & 0 & 1 \\
\hline Air pollution mitigation* & 751 & 3 & 1 & 1 & 5 \\
\hline Storm water runoff reduction & 720 & 1.31 & 0.09 & 1.19 & 1.53 \\
\hline Recreation & 752 & 0.09 & 0.71 & 0 & 15 \\
\hline \multicolumn{6}{|l|}{ Underlying factors } \\
\hline Share of forest in $1 \mathrm{~km}$ buffer zone & 767 & 0.04 & 0.12 & 0 & 0.67 \\
\hline Share of grassland in $1 \mathrm{~km}$ buffer zone & 767 & 0.01 & 0.05 & 0 & 0.4 \\
\hline Share of water in $1 \mathrm{~km}$ buffer zone & 767 & 0.12 & 0.17 & 0 & 0.87 \\
\hline Share of built-up area in $1 \mathrm{~km}$ buffer zone & 767 & 0.18 & 0.15 & 0 & 0.71 \\
\hline Productivity potential & 767 & 9.71 & 3.89 & 0 & 1.66 \\
\hline $\begin{array}{l}\text { Distance from farmer residence to the nearest main urban } \\
\text { districts }\end{array}$ & 767 & 10.83 & 5.31 & 2.13 & 28.28 \\
\hline Distance from farmer residence to the nearest minor road & 767 & 0.65 & 1.27 & 0 & 5.52 \\
\hline Share of family members with off-farm jobs & 726 & 0.45 & 0.31 & 0 & 1 \\
\hline
\end{tabular}

Note: Obs. is the number of valid farm household cases for each variable. Indicators with * are ordinal variables, their median values are shown instead of means, and no standard deviation is presented. For units see Table 1 
Table 3 Multiple regression analyses of landscape services and underlying factors

\begin{tabular}{|c|c|c|c|c|c|c|c|}
\hline Underlying factors & Food & Veg_Fruits & Trees & Ponds & Air & Storm & Recreation \\
\hline Area of forest within $1 \mathrm{~km}$ buffer & $0.53 * * *$ & -0.26 & 0.17 & -0.01 & 0.49 & 0.04 & 0.16 \\
\hline Area of grassland within $1 \mathrm{~km}$ buffer & $0.70 *$ & -0.45 & -0.09 & 0.18 & 1.14 & $0.24 * * *$ & 0.54 \\
\hline Area of water within $1 \mathrm{~km}$ buffer & $-0.33 * * *$ & -0.04 & -0.07 & $0.70 * * *$ & 0.48 & $-0.03 *$ & $1.33 * * *$ \\
\hline Area of built-up land within $1 \mathrm{~km}$ buffer & -0.15 & $0.26^{* *}$ & 0.06 & 0.04 & $-1.09 * * *$ & $0.10 * * *$ & 0.18 \\
\hline Production potential & 0.00 & $-0.01 * * *$ & 0.00 & $0.00 *$ & 0.00 & 0.00 & 0.01 \\
\hline Distance from farmer residence to the nearest main urban area & $0.02 * * *$ & $-0.01 * *$ & $-0.01 * * *$ & 0.00 & 0.01 & $0.01 * * *$ & 0.01 \\
\hline Distance from farmer residence to the nearest minor road & $-0.05 * * *$ & $0.05^{* * *}$ & -0.01 & -0.01 & $-0.07 * *$ & $0.03 * * *$ & 0.01 \\
\hline $\begin{array}{l}\text { Share of family members with } \\
\text { off-farm jobs }\end{array}$ & 0.00 & $0.00^{* *}$ & 0.00 & 0.00 & 0.00 & 0.00 & $0.00 *$ \\
\hline Constant & $0.18^{* *}$ & $0.42 * * *$ & $0.14 * *$ & -0.06 & $3.64 * * *$ & $1.15^{* * *}$ & $-0.26^{*}$ \\
\hline Observations & 696 & 696 & 696 & 696 & 716 & 685 & 716 \\
\hline $\mathrm{R}^{2}$ & 0.12 & 0.07 & 0.03 & 0.24 & 0.05 & 0.53 & 0.08 \\
\hline
\end{tabular}

Presented are slopes. $* * * p<0.01, * * p<0.05, * p<0.1$. Landscape services are specified in Table 1

\section{Discussion and conclusion}

We have analyzed the spatial pattern in landscape services provision on the urban-rural fringe of a rapidly urbanizing city in the light of the obtained results. Our hypothesis was only partly confirmed: provisioning services (except ponds) and storm water runoff indeed followed a linear urban-rural gradient. We did find that food provision in more homogenous and larger farms occurred at the rural end of the fringe, in accordance with Kroll et al. (2012) and Turner et al. (2014). However, one type of cash-crop, vegetables and fruits, was more frequent at the urban end of the gradient. In addition, as postulated, the urban end had a higher incidence of ornamental trees, and more spatial heterogeneity and smaller farms. This can be explained by an overruling predominant effect of local characteristics, but also by a methodological difference, i.e. in the aggregation of predominant agricultural products. Farmland use in the peri-urban area tends to be extensive if agricultural products are not profitable, especially when farmers have access to the city and earn more from nonfarm jobs, as demonstrated in studies including Chen et al. (2009), Jiang et al. (2013) and Liu and Li (2006). However, we found no covariance between the share of family members with off-farm job and the prevalence of provisioning services (Fig. 2). This might be related to the right of Chinese farmers to manage farmland belonging to their rural communities

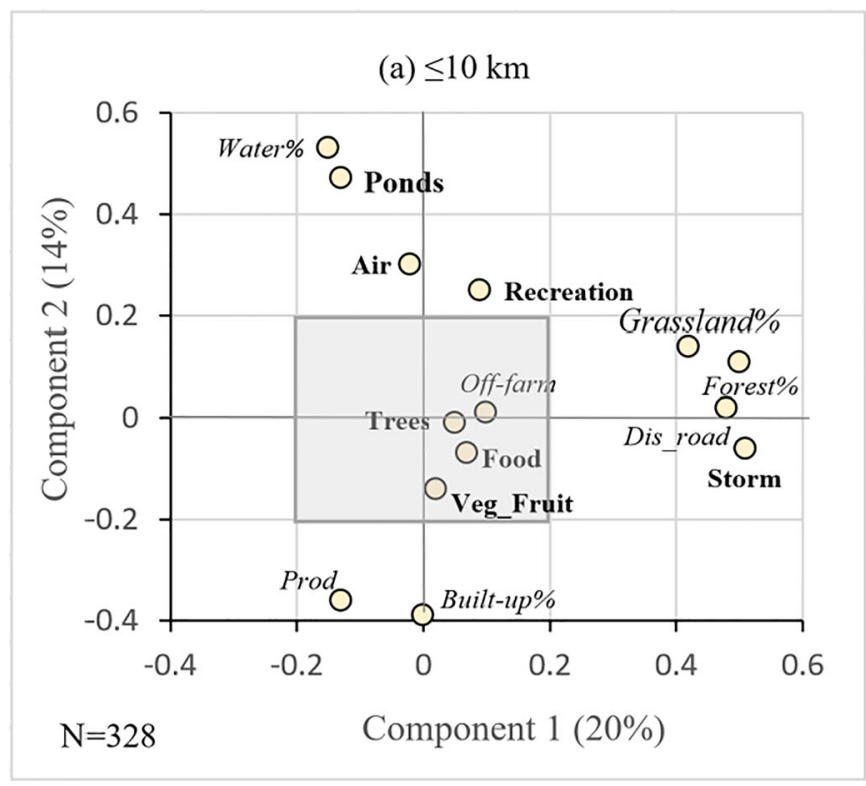

Fig. 2 RDA Loading plot of landscape services and underlying factors on the first and second principal components. For (a) the inner zone within $10 \mathrm{~km}$ of the urban centre, and (b) the zone outside $10 \mathrm{~km}$. The semitransparent box shades variables that are not likely correlated significantly (b) $>10 \mathrm{~km}$

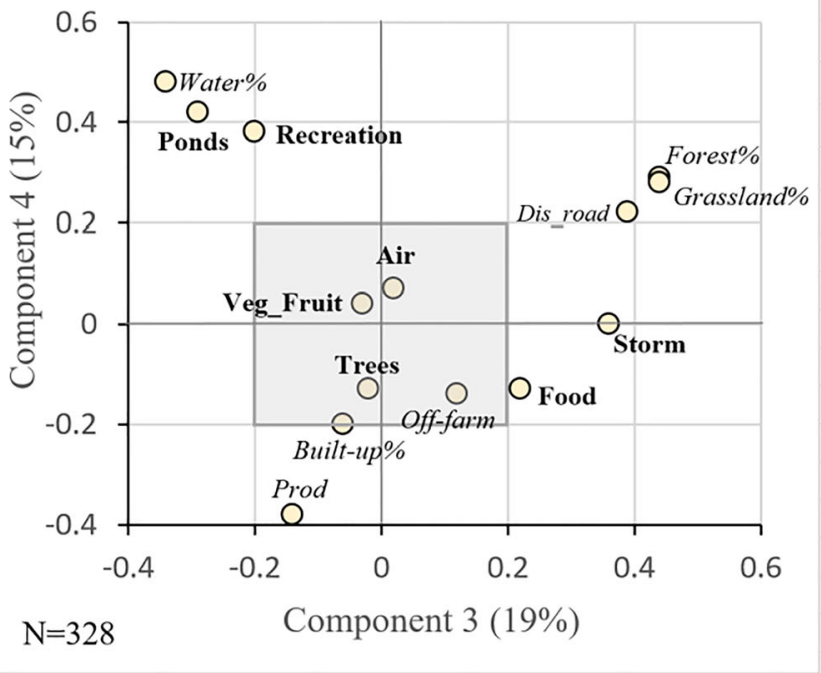

with the principal components. Landscape services and underlying factors are explained in Table 1. Bold refers to services and Italic refers to underlying factors 
without paying a land rent. Therefore, farmers may lack motivation to cultivate despite competing forms of urban use.

Storm water runoff reduction increased towards the rural end, as we postulated, while air pollution mitigation and recreation did not (Table 3). Green infrastructures represented by forest and grassland likely contribute to storm water runoff reduction, while these areas concentrate at the rural end. Our study underlines the importance of maintaining green infrastructures in an expanding urban zone.

Recreation was not found to relate linearly with urban proximity, but rather covaried with ponds, especially towards the rural end of the gradient (Fig. 2). This may be due to the high abundance of waterbodies in Wuhan. Our finding corresponds to the work of Yang et al. (2015), who observed that some services are clearly land-cover dependent (notably provisioning services) whereas others require more narrow line elements, such as rivers. The absence of a significant covariance of recreation with forests is likely to be explained by their limited availability in Wuhan, and the alternative provided by water as well as cultural preferences in Wuhan.

Interestingly, food provision was not found to correspond with the production potential of the farmland, but did covary with the distance to the main urban area (Table 3). This may suggest that potentially productive land in this area is already occupied by an expanding city in the current urban fringe. We can expect that easily accessible farmland is more prone to urban development, providing farmers with less incentive to invest and manage these lands. This finding differs from studies that emphasized the importance of urban proximity to limit transport costs for farming and allowing easier access to markets (Strijker 2005; Terres et al. 2015).

When drafting our hypotheses we observed that the literature has not yet converged on a common theory on how landscape service provision would covary along the urban-rural gradient, and on what would be the major underlying drivers. Our own data suggest a comparatively simple bundle of provisioning (food, Turner et al. 2014) and regulating services (storm water runoff reduction) toward the less impermeable outer rural end of the gradient. Recreation, however, appears driven by the availability of lakes, which does not conform to that gradient. This is at odds with e.g. the findings of Raudsepp-Hearne et al. (2010) and Larondelle and Haase (2013), most likely because different underlying drivers are predominant. We would like to argue for a comparative approach (as in Larondelle and Haase 2013) and an inclusion of underlying drivers that can explain the observed patterns, because we see that the primary drivers are both geographical (around Quebec soil imperviousness is not relevant) and socio-economical (the pressure of human population density in Wuhan is much larger than in the other studies). Furthermore, we feel that theory development on the geography of urban-rural gradients (Zasada et al. 2012) would benefit from empirical groundwork. An increasing demand for cultural landscape services has been documented in periurban areas in Spain (Martín-López et al. 2012), Denmark (Turner et al. 2014), and Sweden (Queiroz et al. 2015). It has been argued that cultural service provision can be synergetic with provisioning services and regulating services, because cultural services are less land-use dependent (Turner et al. 2014). This implies a potential for optimizing the provision of landscape services by mitigating the trade-offs between services in the urban-rural fringe, as was shown in Queiroz et al. (2016). In Wuhan, and other rapidly expanding urban centres, we see great potential for a stronger focus on such synergies and trade-offs in strategic spatial planning rather than laissez-faire policies.

Acknowledgements This study was supported by the China Scholarship Council. Thanks to the contribution of the students who had joined this survey from the College of Public Administration, Huazhong Agricultural University.

Open Access This article is distributed under the terms of the Creative Commons Attribution 4.0 International License (http:// creativecommons.org/licenses/by/4.0/), which permits unrestricted use, distribution, and reproduction in any medium, provided you give appropriate credit to the original author(s) and the source, provide a link to the Creative Commons license, and indicate if changes were made.

\section{References}

Bontje M (2001) Dealing with deconcentration: population deconcentration and planning response in polynucleated urban regions in northWest Europe. Urban Stud 38(4):769-785

Bryant C, Johnston T (1992) Agriculture in the city's countryside, Department for environment, food and rural affairs. Belhaven Press, London

Casado-Arzuaga I, Madariaga I, Onaindia M (2013) Perception, demand and user contribution to ecosystem services in the Bilbao metropolitan greenbelt. J Environ Manag 129:33-43

Chen Y, Li X, Tian Y, Tan M (2009) Structural change of agricultural land use intensity and its regional disparity in China. J Geogr Sci 19(5): $545-556$

China Meteorological Administration (2016) Yearbook of Meteorological Disasters in China. http://www.cma.gov.cn/

Cui Q, Pan Y, Yang X (2015) Beijing plain area of remote sensing images based on Landsat 8 impermeable layer coverage estimates. Journal of Capital Normal University (Natural Science Edition) (in Chinese) 36(2):89-92

Dale V, Polasky S (2007) Measures of the effects of agricultural practices on ecosystem services. Ecol Econ 64(2):286-296

Früh-Müller A, Hotes S, Breuer L, Wolters V, Koellner T (2016) Regional patterns of ecosystem services in cultural landscapes. Land. 5(17)

Gilhespy I (2013) Beyond the fringe: the role of recreation in multifunctional urban fringe landscapes. Journal of Urban and Regional Analysis 2:143-152

Government of Hubei province (2016) http://gkml.hubei.gov.cn/ auto5539/auto5540/201611/t20161118 919628.html

Haines-Young R, Potschin M (2010) Proposal for a common international classification of ecosystem goods and services (CICES) for integrated environmental and economic accounting (V1). Report to the 
European Environment Agency. Department of Economic and Social Affairs Statistics Division, United Nations, Nottingham, UK

Hou Y, Mller F, Li B, Kroll F (2015) Urban-rural gradients of ecosystem services and the linkages with socioeconomics. Landscape Online 39(1):1-31

Hubei Bureau of Statistics (2015) Wuhan Statistical Yearbook. http:// www.stats-hb.gov.cn/upload/nj/2015whnj.pdf

IIASA/FAO, Fischer G, Nachtergaele F, Prieler S, Van Velthuizen HT, Verelst L, Wiberg D, IIASA/FAO (2012) Global Agro-ecological Zones (GAEZ v3.0), IIASA, Laxenburg, Austria and FAO, Rome, Italy. iv. https://doi.org/10.1029/97GB03657

Jiang L, Deng X, Seto K (2013) The impact of urban expansion on agricultural land use intensity in China. Land Use Policy 35:33-39

Koschke L, Fürst C, Frank S, Makeschin F (2012) A multi-criteria approach for an integrated land-cover-based assessment of ecosystem services provision to support landscape planning. Ecol Indic 21:54 66

Kroll F, Müller F, Haase D, Fohrer N (2012) Rural-urban gradient analysis of ecosystem services supply and demand dynamics. Land Use Policy 29(3):521-535

Langemeyer J, Baró F, Roebeling P, Gómez-Baggethun E (2014) Contrasting values of cultural ecosystem services in urban areas: the case of park Montjuï in Barcelona. Ecosystem Services 12: $178-186$

Larondelle N, Haase D (2013) Urban ecosystem services assessment along a rural-urban gradient: a cross-analysis of European cities. Ecol Indic 29:179-190

Liu C, Li X (2006) Regional disparity in the changes of agricultural land use intensity in China during 1980-2002. J Geogr Sci 16(3):286292

Liu X, Li X, Shi X, Zhang X, Chen Y (2010) Simulating land-use dynamics under planning policies by integrating artificial immune systems with cellular automata. Int J Geogr Inf Sci 24:783-802

Liu L, Xu X, Chen X (2014) Assessing the impact of urban expansion on potential crop yield in China during 1990-2010. Food Secur 7:3343. https://doi.org/10.1007/s12571-014-0411-z

Łowicki D, Walz U (2015) Gradient of land cover and ecosystem service supply capacities- a comparison of suburban and rural fringes of towns Dresden (Germany) and Poznan (Poland). Procedia Earth and Planetary Science 15:495-501

Martín-López B, Iniesta-Arandia I, Garcia-Llorente M, Palomo I, CasadoArzuaga I, Del Amo DG, Gomez-Baggethun E, OterosRozas E, Palacios-Agundez I, Willaarts B, Gonzales JA, SantosMartin F, Onaindia M, Lopez-Santiago C, Montes C (2012) Uncovering ecosystem service bundles through social preferences. PLoS One 7(6):e38970

Pandit A, Gopalakrishnan G (1996) Estimation of annual storm run-off coefficients by continuous simulation. J Irrig Drain Eng 122(4):211220

Pearson L, Pearson L, Pearson C (2010) Sustainable urban agriculture: stocktake and opportunities. Int J Agric Sustain 8(1):7-19

Plieninger T, Dijks S, Oteros-Rozas E, Bieling C (2013) Assessing, mapping, andquantifying cultural ecosystem services at community level. Land Use Policy 33:118-129

Queiroz C, Meacham M, Richter K, Norström A, Andersson E, Norberg J, Peterson G (2015) Mapping bundles of ecosystem services reveals distinct types of multifunctionality within a Swedish landscape. AMBIO 44:S89-S101
Radford K, James P (2013) Changes in the value of ecosystem services along a rural-urban gradient: a case study of greater Manchester, UK. Landsc Urban Plan 109(1):117-127

Raudsepp-Hearne C, Peterson G, Bennett E (2010) Ecosystem service bundles for analyzing tradeoffs in diverse landscapes. Proc Natl Acad Sci U S A 107(11):5242-5247

Rossi S, Byrne J, Pickering C (2015) The role of distance in peri-urban national park use: who visits them and how far do they travel? Appl Geogr 63:77-88

Seto K, Güneralp B, Hutyra L (2012) Global forecasts of urban expansion to 2030 and direct impacts on biodiversity and carbon pools. Proc Natl Acad Sci U S A 109(40):16083-16088

Simon D (2008) Urban environments: issues on the peri-urban fringe. Annu Rev Environ Resour 33(1):167-185

Soil Conservation Service (SCS) (1972) National engineering handbook, section 4: hydrology. Department of Agriculture, Washington DC 762

Strijker D (2005) Marginal lands in Europe - causes of decline. Basic and Applied Ecology 6(2):99-106

Suarez-Rubio M, Lookingbill T, Wainger L (2012) Modeling exurban development near Washington, DC, USA: comparison of a pattern-based model and a spatially-explicit econometric model. Landsc Ecol 27(7):1045-1061

Terres J, Scacchiafichi L, Wania A, Ambar M, Anguiano E, Buckwell A et al (2015) Farmland abandonment in Europe: identification of drivers and indicators, and development of a composite indicator of risk. Land Use Policy 49:20-34

Torres-Lima P, Rodríguez-Sánchez L (2008) Farming dynamics and social capital: a case study in the urban fringe of Mexico City. Environ Dev Sustain 10(2):193-208

Turner K, Odgaard M, Bøcher P, Dalgaard T, Svenning J (2014) Bundling ecosystem services in Denmark: trade-offs and synergies in a cultural landscape. LLandsc Urban Plan 125:89-104

United Nations (2014) World urbanization prospects: the 2014 revision. United Nations, Department of Economic and Social Affairs, Population Division, New York). Available at www.un.org/en/ development/desa/publications/2014-revision-worldurbanizationprospects.html Accessed 17 Mar 2015

USDA-NRCS (1986) Urban hydrology for small watersheds. Soil Conservation (Technical Release 55 (TR-55)), 164. http://scholar. google.com/scholar?hl=en\&btnG=Search\&q=intitle:Urban+ Hydrology+for+Small+watersheds\#1

Whitford V, Ennos A, Handley J (2001) "City form and natural process"- indicators for the ecological performance of urban areas and their application to Merseyside, UK. Landsc Urban Plan 57(2):91-103

Wuhan Land Resources and Planning Bureau (2011) http://www.wpl. gov.cn/pc-7-35831.html

Yang G, Ge Y, Xue H, Yang W, Shi Y, Peng C, Du Y, Fan Y, Ren Y, Chang J (2015) Using ecosystem service bundles to detect trade-offs and synergies across urban-rural complexes. Landsc Urban Plan 136:110-121

Zasada I, Loibl W, Berges R, Steinnocher K, Köstl M, Piorr A, Werner A (2012) Rural-urban regions: a spatial approach to define urbanrural relationships in Europe. Peri-urban futures: scenarios and models for land use change in Europe:45-68 